\title{
Folkemindeforskeren F. Ohrt.
}

Af August F. Schmidt.

I Fremmedherredømmets Tid

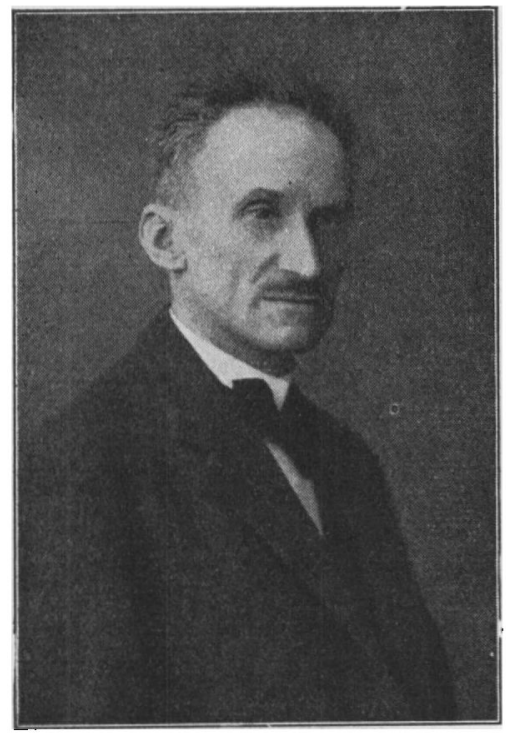
sagte flere af Sønderjyllands videnskabelige Begavelser nordpå og øvede deres Indsats i Kongeriget. Til disse hørte den Mand, hvis Livsgerning her kortelig skal omtales.

Ferdinand Christian Peter ohrt blev født på S a n d b jerg i Sundeved den 1 \%. November 1873. Hans Forældre var Godsinspektor Andreas Nicolai Christoph Ohrt (død 1917) og Hustru Christine Caroline, født koch (død 1091), der begge var af sønderjydsk Slægt og dansksindede. De horte til den Kreds af Venner, der samledes i $\mathbf{H}$. P. H a n s s e n s Barndomshjem på Nørremølle. Godsinspektøren skildres af H. P. H. som "den altid formelt korrekte $\left.{ }^{1}\right)$, en Optræden, hans Søn Ferdinand Ohrt på smuk Måde tog i Arv. Det er sikkert tidligt blevet opdaget, at den lille Dreng Ferdinand var i Besiddelse af gode Evner. Han fik derfor en god Privatskolegang, undervist af den dygtige Lærerinde, Frk. Hedvig Peterse ${ }^{2}$ ), hvorefter han kom på Sor a A ade $\mathrm{mi}$, hvorfra han tog Studentereksamen 1892. Ved Køben-

1) H. P. Hanssen: Et Tilbageblik (1928), 28.

2) Se F. Ohrts Selvbiografi i Køhenhavns Iniversitets Progrann, November 1923. 
havns Universitet studerede han Theologi og blev cand. theol. i 1898. Under det theologiske Studium grundlagde han sin Viden i semitiske Sprog og i Kirkehistorie. Han er en af de meget få Theologer, der til Embedseksamen opgav hele det gamle Testamente på Hebraisk. Sine Kundskaber i den gamle Pagts Bog frugtbargjorde han i sit i 1915 udgivne Arbejde: "Israels Profeter", der $i$ en ualmindelig fængslende Form giver Oplysninger om Profeternes Betydning for Israels Religion. Theologer omtaler hyppigt Ohrts Bog som den bedste, der findes på Dansk om Emnet, og demne Vurdering sỵnes ikke at kunne modsiges.

Da Ohrt ikke fø!te Kald til at blive Præst, læste han også til Skoleembedseksamen. I 1901: blev han cand. mag. 1902 opnåede han Ansættelse som Adjunkt ved sin gamle Skole i Sorø. Her var han til 1914, da han tog sin Afsked på Grund af Svaghed (Tuberkulose). Efter at have opgivet sin Skolegerning flyttede Ohrt til Kobenhavn, hvor han, den ugifte Mand, tilbragte Resten af sin Levetid, stærkt optaget af videnskabelige Studier.

Allerede $\mathrm{i}$ sit første Studenterår begyndte Ferdinand Ohrt at interessere sig for finsk Sprog og Folkeminder. Hos Vilhelm Thomsen blev han indfort $i$ de finsk-ugriske Sprog, hvis bedste Kender herhjemme Ohrt senere selv skulde hlive. Fra 1920 og en Del År frem i Tiden holdt han som Privatclocent Forelæsninger og Øvelser over finsk Sprog og Litteratur (samt Ungarsk og Estnisk) ved Københavns Lniversitet. I Finland har han som Gæst holdt Forelæsninger på F'insk i Helsingfors.

Ohrt opnåede tidlig et anset Navn som Sprogkender, men det er dog som Folkemindeforsker og Litteraturhistoriker, hall har øvet sin største Indsats.

I 1906 foretog han Viseindsamlinger i Finsk- og RussiskKarelen (senere optaget i Samlerværket "Suomen kansan vanhat runot") og udgav 1907 "Kalevala" I--II, dels en Oversættelse i Udtog, dels en historisk Fremstilling af Kalevala som 
Folkedigtning og Nationalepos; sidste Del deraf blev oversat på Finsk 1909, et Vidnesbyrd om Arbejdets Værdli. Ohrts Kalevalaværk er en videnskabelig Bedrift af høj Rang og er et storartet Udtryk for hans Evner til at trænge ind $i$ et fjernt og vanskeligt Sprog. A x e l Olrik har i Tidsskriftet Danske studier 1908, S. 62-64 givet en anerkendende Vurdering af Kalevalabøgerne. Idet man skal nøjes med at henvise dertil, skal det samtidig anføres, at den Sorø Adjunkt for sine Arbejcler om den finske Folkedigtning allerede i 1907 blev udnævnt til korresponderende Medlem af Det finske Litteraturselskab i Helsingfors. Adskillige År senere blev han Kommandør af Finlands hvide Rose.

Det faldt naturligt for Ferdinand Ohrt at meddele sine sinderjydske Landsmænd Oplysninger om de sproglig-historiske Forhold i Finland, Nordens Vagt mod Øst. Derfor offentliggjorde han i 1912 i Sønderjydske Árbøger den første eksistereende fyldige Overisgt over Forholdet mellem Finsk og Svensk i Finland, et udmærket Bidrag til Nationalitetsforholdenes Historie i Europa.

For en Sprogforsker med Ohrts Øvelse i at optegne Folkeminder og Dialektudtryk i vanskelige østeuropæiske Sprog var det en let Sag også at yde et selvstændigt Stykke Arbejde indenfor Studiet af danske Dialekter. Det er da nemt at forstå, at han nu gik til den modsatte Ydergrænse, sả langt mod Sýd som Dansk taltes og forstodes af ældre Almuefolk, nemlig i Fjolde Sogn i Sydslesvig. Her foretog Ohrt i 1912 Indsamlinger af dansk Sprog og Folkeminder. Han mener selv at have udspurgt de samme Mennesker, som J. B. Hø y e r i 1907 havde besogt. Et samlet Resultat af sine Sprogstudier i Fjoldeegnen har Ohrt offentliggjort i Danske Studier 1919, 61-70 i Afhandlingen: "Fra den yderste Sproggrænse". Alle danske Filologer, der har beskæftiget sig med de sønderjydske Dialekter, eller som i Dag arbejder med det sydligste Dansk, har hver især gjort Turen om ad Fijolde, hvorfor der er en hel 
Litteratur om denne afsides Egns (lanske Sprogrester. ${ }^{1}$ ) Ikke mindst efter 1920 har danske Sprogmand hjemsøgt hint Sogn, hvad man bl. a. får interessante Oplysninger om i Anders B jerrums køme skildring af Ga m le T'in ne,") der levede i Tiden 1841-1937 i Fjolde Sogn. Hun kunde tale Egnens nu uddøde danske Dialekt. I Fjoldeforskernes Række hører Ohrt hjemme i den ældre Falanks - sammen med P. K. Thorsen, J. B. Høyer og Marius Kristensen.

Da Foreningen "Danmarks Folkeminder« i 1919 på sin særlige Måde vilde give Udtryk for Glæden over Sønderjyllands Tilbagevenden til Moderlandet, blev det overdraget Sonderjyden F. Ohrt at udgive et til den store Anledning passende Arbejde. Overvejelserne førte til, at der til Genforeningen blev offentliggjort en mindre, festligt udstyret Sagnbog: "Udvalgte sanderjydske Folkesagn« $(1919,94$ S.), illustreret med prægtige Tegninger af $\mathrm{J}$ oakim og $\mathrm{Ni}$ els $\mathrm{Sk}$ ovgaard. Bogen var tænkt som en lille Festgave især til sønderjydske Børn, men dog i den liorventning at også Voksne Syd og Nord for Kongeåen vilde kunne bruge den. Forhåbentligt or denne Forventning gảet i Opfyldelse. Stoffet i denne den finest udstyrede Sagnsamling i Danmark er jo Sønderjydernes eget. Med stor Glæde har mange i $\mathrm{F}$. Ohrts vel redigerede og godt kommenterede Sagnudvalg fået deres første Indførelse $i$ den sønderjydske Sagnverden. Det er smukt at tænke på, at det skulde blive vor bedste Kender af de fjerneste østnordiske Folkeminder, Inspektørsønnen fra Sandbjerg i Sundeved, der kom til at udgive den danske Folkemindeforenings Hjemkomsthilsen til vore Folkefæller sønden A.

I denne Forbindelse kan det være passende at nævne et betỵdeligt senere Værk af Ohrt, hans Bog: "Gamle Tiders Finland «, der udkom 1932. Heri er givet en Fremstilling af Fin-

1) Se Henvisninger i Sønderjydske Arlogger 1938, 59, 200.

2) Danske Folkemaal 1937-38, 1-8. 
lands Historie fra Oldticlen og til 1809, da Rusland amnekterede det estligste Rige i Norden. "Gamle Tiders Finland " er naturligvis en ypperlig Bog, fængslende skrevet og præget af Forfatterens Forstehåndskendskab til Landets Sprog, Historie og Natur. Man erfarer stærkt af Ohrts Arbejde, at det finske Folk gennem Arhundrederne har været underkastet vaerre Provelser end noget andet nordisk Land. Hungersnod og Polarkulde, Krige og Vold, Rædselsherredømme, Myrderier, Sult, Krige, Massakrer ...., det er det Indtryk, der sidder tilbage i Erilldringen selv adskillige Ar efter, at man med beveget sind har lasst Bogen om det tapre og nøjsomme finske frolks Tilskikkelser.

Under sit Studium af finske Folkeminder blev Ohrt ret snart gjort bekendt med den righoldge finske Overlevering af Trylleformularer, Galder og Sejd, Heksekunster og Magi. Han gav sig så til at undersøge, om vi havde en nævıeværdig Overlevering af lignende Folkemindestof i Danmark. Dette viste sig at være Tilfældet. For at få et Udgangspunkt for Studiet af de danske Try!leformler samlede Ohrt et stort Materiale fra vort Land. Det blev udgivet $i$ de to Bind: "Danmarks 'Trylleformler $\left.(1917-21),{ }^{\prime}\right)$ en velordnet samling, let at henytte for lorskerne og indeholdende mange særegne Oplysninger om gammel Tro og Skik. F. Ohrt har selv med fremragende videnskabelig Dygtighed $i$ en Hakke Bøger og Afhandlinger tolket sikkert de fleste vanskelige Problemer $i$ det danske Trolddomsstof. Han har derved ogsa kastet Lys over de ovrige europæiske Landes Trylleformularer, idet Folkeminder af denne Art er internationale og ikke respekterer Landegrænser.

Et Forsteindtry af Ohrts L'ndersogelser af Europas Trylleformler fra Oldtid til Nutid findes $i$ hans Bog: "Trylleord,

1) Siden 1921 har Ohrt ved stadig Agtpågivenherl fundet endnu en Del Trylleformler. Der er nok til et Bind, hvis trykferclige Manuskript findes i Dansk Folkemindesamling. 
fremmede og danske« (1922), et sjældent smukt og fængslende Arbejde, holdt $i$ så let tilgængelig Form, at enhver interesseret med rigt Udbytte kan læse Bogen, der i fortrinlig Grad er præget af Ohrts udmærkede stilistiske Evner. - I den lærde Undersøgelse: "Vrid og Blod" (1922) giver Ohrt bl. a. en Tolkning af den af Forskerne meget omdisputerede Merseburgerformel. "Vrid og Blod" er Ohrts Disputats. Den akademiske Handling var meget ærefuld for den ansete Doktorand.

Fem Ar senere udgav Ohrt sin største Bog: "Da signert lirist - " (1927), der, idet den indeholder en Række Tolkninger af europæiske Trylleformler, giver Oplysninger om Formlernes Vandringer gennem vor Verdensdels Lande og skildrer de historiske og religigse Forudsætninger for 'Trylleformularer og for de hedenske og lavkirkelige Forestillinger, der kan sættes i Forbindelse med Trolddom og Magi. Ohrt har ved Udarbejdelsen af "Da signed Krist - " rigtig haft Brug for sine mangfoldige Sprogkundskaber og for sin theologiske Lærdom. Man beundrer under Læsningen af det store Værk idelig den glimrende Begavelse, der har gjort det muligt at udarbejde en Bog som den omtalte. Ohrt havde i Arenes Løb opøvet en enestående Evne til at læese Lønsprog, Cyprianusser, Abracadabraer, bagvendt Snak og andet lignende forbistret Hovedbrud, undfanget i gamle trolddomskyndige Rebusmageres subtile Hjærner eller i lærde Mageres Kryds- og Tværs-Hoveder. Men al deres sammenkogte Tankesejd og blodskrevne Tryllespind blev - năr Dr. Ohrt havde kigget en Tid derpå - opløst og udredet, glattet lige og bragt i Ordell, så der intet dunkelt blev tilbage - uden måske Forundringen over det åndelige Mørke, Millioner af Mennesker har levet i, når man tænker pá, hvilke Midler det i Virkeligheden var, de havde at støtte sig til, at søge Hjælp hos mod Sygdomme og Sot, onde Mennesker og vilde Dyr, mod Torden og Lynild, Vandflod og store V'inde.

I 1928 udsendte Ohrt den smukke lille Bog: "Gamle danske Folkebonner", der slutter sig til de tidligere storre Arbej- 
der vedrørende Tolkningen af de europæiske - og danske Trylleformler. Hertil kommer så en lang Række mindre Undersøgelser, offentliggjorte i Tidsskriftet Danske Studier, i dell internationale Serie: Folklore Fellows Communications (udgår fra Helsingfors) samt i andre danske og udenlandske Fagtidsskrifter.

Ohrts Undersagelser i Trylleformler gav ham et europæisk kendt Navn i Fagkredse. Han hævder i sine Studier de kristne Forestillingers overordentlige Betydning for mytologiske og magiske Overleveringer fra Overgangstiden mellem Hedenskab og Kristendom. Han holder på Lignelsernes lavkirkelige naive Oprindelse og opfatter dem ikke som lærd Symbolik. Ohrt var i sin Forskning påvirket af den finske folkloristiske Skole. livis Førstemand var $\mathrm{K}$ a a r le $\mathrm{Kroh}$.

F. Ohrt var den eneste danske Medarbejder ved den store i Basel redigerede Handwörterbuch des deutschen Aberglaubens, en Forbindelse han satte Pris på og med Rette betragtede som en stor Anerkendelse.

Dr. Ohrt blev i 1931 Medlem af det kgl. danske Videnskabernes Selskab, den højeste Anerkendelse en dansk Lærd kan opnå. Person!ig var han en yderst stilfærdig og beskeden Mand, der aldrig lod sig mærke med sin sjældne Lærdom. Han benyttede sig af et forsigtigt, høfligt sprog, og kunde $i$ et nindre Selskab være grumme hyggelig, fuld af And og Vid, isprængt mild Sarkasme. Han følte sig med Årene nær knyttet til Arkivar H. Grün e $-\mathrm{N}$ i els e n, med hvem han foretog en Finlandsrejse. Nærv. Forf. har de herligste Stunder at tænke tilbage på, når han mindes Samvær med de to Folkemindeforskere. Deres Samtaleform var af en egen kostelig Art, kun givet til de enkelte, særlig benådede Konversatorer. Det er iøvrigt let at forstå, at også Dr. Ohrt følte sig tiltrukket af Grüner-Nielsen, der som vor ypperste Folkeviseforsker kunde have meget at tale med Kalevalas Oversætter om. ${ }^{1}$ )

1) H. Grüner-Nielsen har skrevet Biografien af Ohrt i Dahls \& Engelstofts Dansk biografisk Haandleksikon III (1926), 23. 
F. Ohrts videnskabelige Gerning er af så høj Værdi, at han stedse vil indtage en"førende Plads indenfor Folkemindeforskningen. Han er den danske Folklorist, der har besiddet den største Sprogviden, og siden Axel Olriks og H. F. Feilbergs Dage var han den læerdeste indenfor sit Fag i vort Land. Igennem mange År kæmpede Ohrt med et dårligt Helbred, sả det er egentligt ikke let at forstå, at han kunde ná at udrette så meget, som han gjorde. I Efteråret 1938 lakkede det mod Enden. Den 5. December om Aftenen afgik Ferdinand Ohrt stille og roligt ved Døden på Sct. Josephs Hospital i København. 65 År gammel. Søndagen den 11. December 1938 (KI. 1丷) begravedes han fra Vester S ot trup Kirke i Sundeved. Den vidtberejste Mand gnskede at komme til at hvile på sin Hjemstavns Kirkegård. Her kan man nu dvæle ved hans sidste Lejested. Her er meget at takke for. F. Ohrt er en af Sømderjyllands største Begavelser. Sønderjydske Landsmand bør værne Mindet om ham, en af deres bedste Udsendinge, den stilfærdige Forsker, der levede stærkt med i sin Stammes nationale Nod, og som kastede Glans over dansk Videnskab. 